Jurnal Teknologi, 54 (Sains \& Kej.) Keluaran Khas, Jan. 2011: 23-30

(C) Universiti Teknologi Malaysia

\title{
DEVELOPMENT OF PORTABLE ELECTRONIC NOSE DEVICE FOR PERFUME ODOUR CLASSIFICATION
}

\author{
FAUZAN KHAIRI CHE HARUN ${ }^{1}$, NUR ATIQAH IBRAHIM ${ }^{2}, \&$ \\ MOHD ARIFFANAN MOHD BASRI ${ }^{3 *}$
}

\begin{abstract}
This paper presents the development of a portable electronic nose (e - Nose) based on a National Instrument data acquisition card and LabView. The study includes the design of eNose circuits that consist of different types of metal oxide semiconductor from FIGARO as gas sensors. The resistances of each gas sensor are measured through a constant current circuit controlled via LabView. The constant current source is used as an adaptive electronic interface that allows the accurate mapping of the sensor's voltage output to sensor resistance profiles. The resistance of each sensor is accurately computed and displayed by LabView. The result of the study showed that the created e - Nose can detect and classify between two famous brands Body Shop and Avon. The applied principal component analysis (PCA) method shows great discrimination of $99.53 \%$ for the mentioned odour. This suggests that the system is able to discriminate between simple odours and will be use for a more complex task in the future.
\end{abstract}

Keywords: Electronic Nose: metal oxide semiconductor; gas sensor; pattern recognition; PCA

\begin{abstract}
Abstrak. Artikel ini membentangkan pembangunan sebuah hidung elektronik (e - Hidung) mudah alih berdasarkan kad perolehan data National Instrument dan LabView. Kajian ini merangkumi rekabentuk litar e-Hidung yang terdiri daripada pelbagai jenis semikonduktor oksida logam daripada FIGARO sebagai sensor gas. Rintangan dari setiap sensor gas diukur melalui litar arus tetap yang dikawal melalui LabView. Sumber arus tetap digunakan sebagai antara muka elektronik bolehubah yang membolehkan pemetaan voltan keluaran sensor untuk profil rintangan sensor dilakukan secara tepat. Rintangan dari setiap sensor dikira secara tepat dan dipaparkan oleh LabView. Keputusan kajian menunjukkan bahawa e - Hidung yang dihasilkan boleh mengesan dan mengklasifikasikan antara dua jenama terkenal iaitu Body Shop dan Avon. Kaedah analisis komponen utama (PCA) yang digunakan menunjukkan diskriminasi besar iaitu 99.53\% untuk bau tersebut. Ini menunjukkan bahawa sistem yang dihasilkan mampu membezakan baud an akan digunakan untuk tugas yang lebih kompleks pada masa akan datang.
\end{abstract}

1-3 Faculty of Electrical Engineering, Universiti Teknologi Malaysia, 81310, UTM Johor Bahru, Johor Darul Ta'azim, Malaysia

* Corresponding author: ariffanan@fke.utm.my 
Kata kunci: Hidung elektronik; semikonduktor oksida logam; sensor gas; pengecaman corak; PCA

\subsection{INTRODUCTION}

Electronic Nose (e - Nose) is a device used to detect and recognize odours or vapours, i.e. a machine olfaction device with an array of chemical sensors. The electronic nose was created in order to resemble the human nose in several aspects. Currently, many researches are being done to improve the sensitivity of enose by utilizing different type of sensor or technique for various applications [1, 2]. In biomedical field, many research has utilize e-nose as their method of illness or disease detection such as detection of diabetes [7], urinary tract infection from urine odour [8], and lung cancer detection from breath [9, 10]

Essentially, the olfactory neurons are mimicked by the chemo resistive sensors with the different sensitivity to different gases. Then, the responses will be transported to the brain that is mimicked by the pattern recognition system where gas classification and identification takes place. Samples with different gases show differences in their patterns, similar to a fingerprint pattern [3]. Each gas will generate a different chemical response fingerprint when applied to the e-nose. When the patterns for a series samples are compared, the differences can be correlated with the perceived gas.

There are few reasons why the e - Nose are created. First, due to the sensory profiling by human taste panel is affected by external factors and usually inaccurate because of a lack of either sensitivity or quantitative information. Second, infection can take place which may affect the ability to smell. Besides that, in some cases that gases can brings invasive effect towards human when they sniff off the gases [4].

The innovation of e-nose is intended to enhance the human way of life, so a portable and affordable e-nose is crucially needed [5]. So, the main objective of this project is to create a portable electronic nose that can detect and discriminate among volatile organic compounds using an array of metal oxide semiconductor sensors. From this system, we will be able to classify the samples of volatile organic compounds in specific group by using PCA approach. In the future, the researcher envisions the e-nose will be embedded in mobile phone for consumers to utilize 


\subsection{METHODOLOGY}

A model of electronic nose was built from four types of metal oxide semiconductor sensors from Figaro Sciences with different sensitivity, specifically the TGS2440, TGS800, TGS 840 and TGS2200. Two different brand perfumes were chosen in this project as test sample, which is from Body Shop and Avon.

The outcome of electronic nose signals were displayed and collected by LabView programming. Then, PCA method is used to discriminate the response of an electronic nose in group classification.

\subsection{Electronic Nose Circuits}

Electronic nose system basically is a combination of voltage regulator, constant current source and an array of sensors. The block diagram is shown in Figure 1. The electronic circuitry will be controlled via LabView through a National Instrument USB6008 DAQ card.

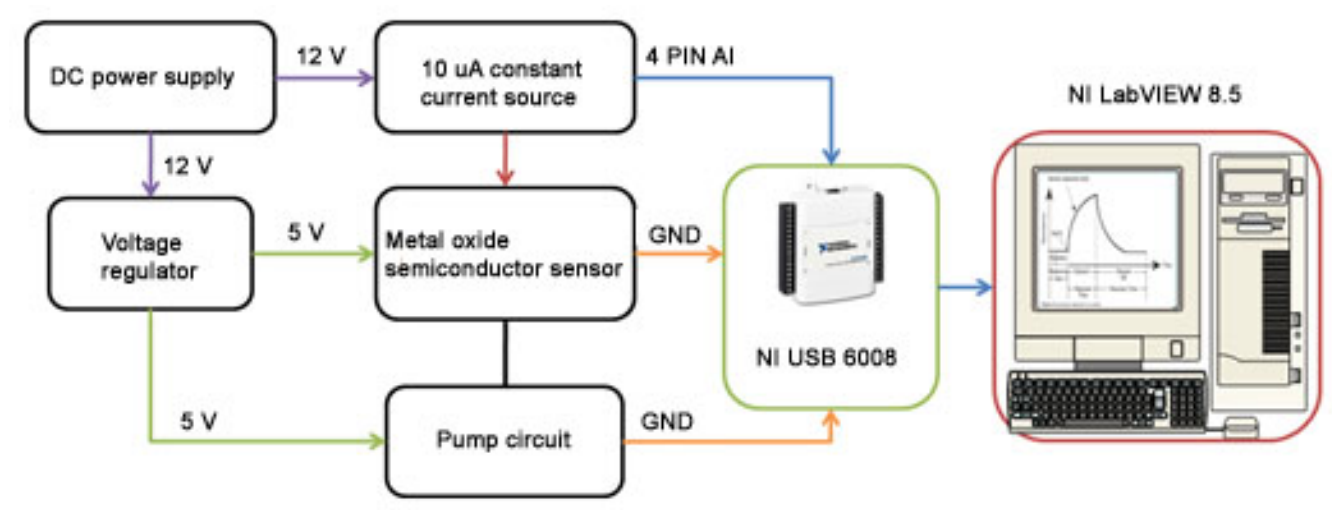

Figure 1 Block diagram of an electronic nose system

\subsubsection{Voltage Regulator}

Voltage regulator circuit is used to regulate voltage from 12 Volt to 5 Volt power supply. The sensors that being used and vacuum pump need 5 Volt voltage source to operate that is regulated by a 7805 integrated circuit. 
The circuit can give +5 Volt output at about $150 \mathrm{~mA}$ current, but it can be increased to 1 Ampere when good cooling (heat sink) is added to LM7805 IC. The circuit is provided with overload and terminal protection utilizing fuses.

\subsubsection{Constant Current Source}

Four LM334 ICs are used to build $10 \mu \mathrm{A}$ constant current source circuits for each metal oxide sensor in the electronic nose. LM334 ICs are chosen to provide constant current source in this project due to their ability to produce a small current value from $1 \mu \mathrm{A}$ to $1 \mathrm{~mA}$ by changing the value of $\mathrm{R}_{\mathrm{Ser}}$ connected to the circuit. Fig 3 shows the configuration of constant current source for a $10 \mu \mathrm{A}$ current.

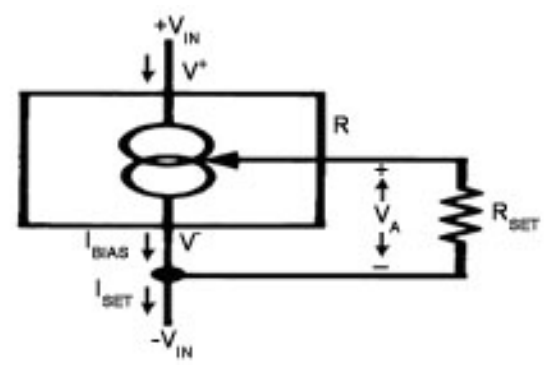

Figure 3 A $10 \mu \mathrm{A}$ constant current source circuit

\subsection{Lab View Programming Structure}

The data acquisition and storage system controlled using LabView 8.5 software. LabView is used to control the pump, valve and ADC connected to the system. An automated e-nose system has been designed with the user only controlling the time for test and flush.

\subsection{Experiments}

There are five experiments to be conducted for each perfume in order to observe the response signals of sensors array in electronic nose system. 


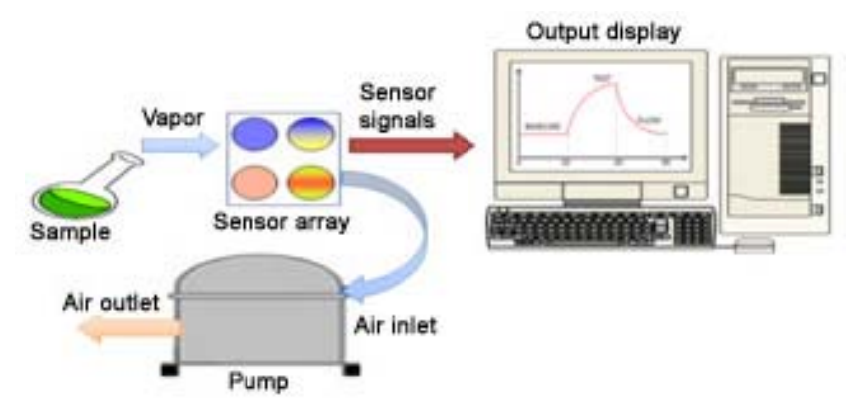

Figure 4 Experiments set up of electronic nose

Based on Figure 4, the experiment begins with the sample bottle which has sample's headspace are connected to the electronic nose. Then, the sample's headspace was be pulled by the vacuum pump inside the electronic nose through tubing into a chamber of sensors array at a certain flow rate.

Basically, the responses of electronic nose are based on three time cycles as shown in Figure 5. There are baseline time, response time and recovery time. Baseline time is referred to reference gas or in other words, the air conditions before inhaling process occur. Response time is the time when the system exposes to an odorant. While, the recovery time means the time during takeoff odorant from the system or can be said as cleaning time system.

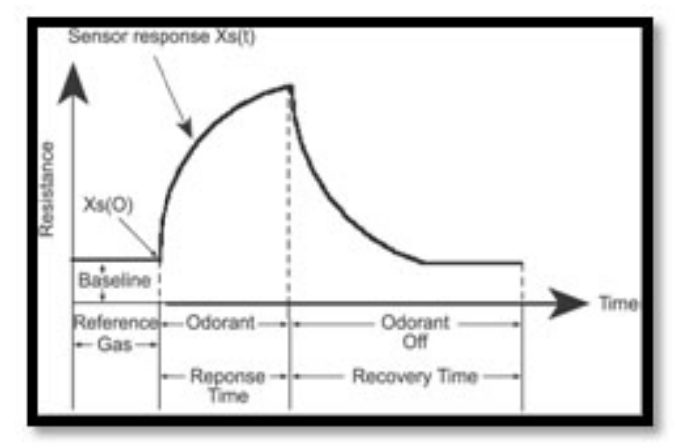

Figure 5 Electronic nose response to an odorant

Later, the gas sensor which was exposed to the odour produces a transient response due to chemical reaction between the sensor and odour. The magnitude of response will be related to the chemical reaction that occurs. The reason of 
using more than one gas sensor for e-nose is so that all of them will respond differently to the same odour, thus giving us a pattern of response for each test sample. During the sensor response, the voltage of gas sensor is recorded and delivered to the signal processing unit. The signal from all the sensors are collected and combined by the computing system. Then, PCA is used to analyze the odour quantitatively.

\subsection{RESULTS AND DISCUSSION}

Detection responses of all sensor elements were measured for both perfumes, Body Shop and Avon in order to observe their performance. Fig. 6 and Fig. 7 show the resistance response profile of the four gas sensor (TGS2440-red, TGS800-blue, TGS 840-cyan and TGS2200-white) to odour of Body Shop and Avon perfumes respectively. Comparatively, the response of sensor array to Body Shop perfume is faster compared to the Avon perfumed. However, the recovery time for Avon perfume is much faster. Furthermore, for Avon perfume one of the sensors did not give a significant response to the odour. Even here we can differentiate the gas sensor response without any processing. More complex odour such as essential oil would require more processing to distinguish between them.

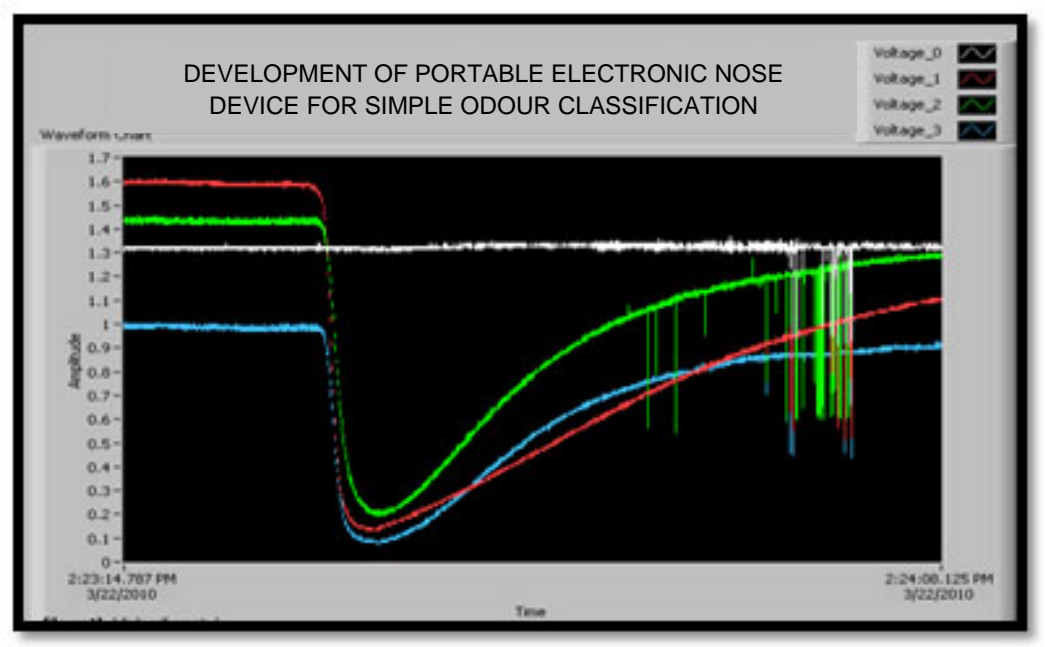

Figure 6 Response of each sensor in electronic nose to the aroma of Body Shop Perfume 


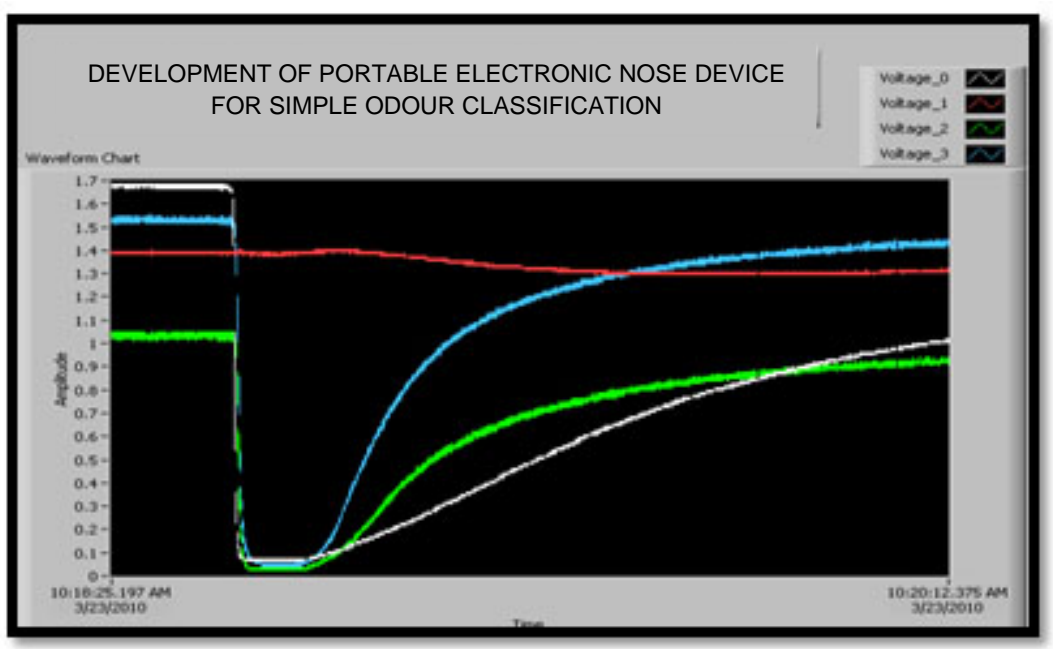

Figure 7 Response of each sensor in electronic nose to the aroma of Avon Perfume

Based on the both figure above, we can see that each sensor in electronic nose have different sensitivity to different scent. Then, PCA approach is applied to view performance electronic nose in classification of odour. Fig. 8 shows the results from PCA approach. Separation between the aromas was distinct for the two test sample that we achieve $99.52 \%$ separation.

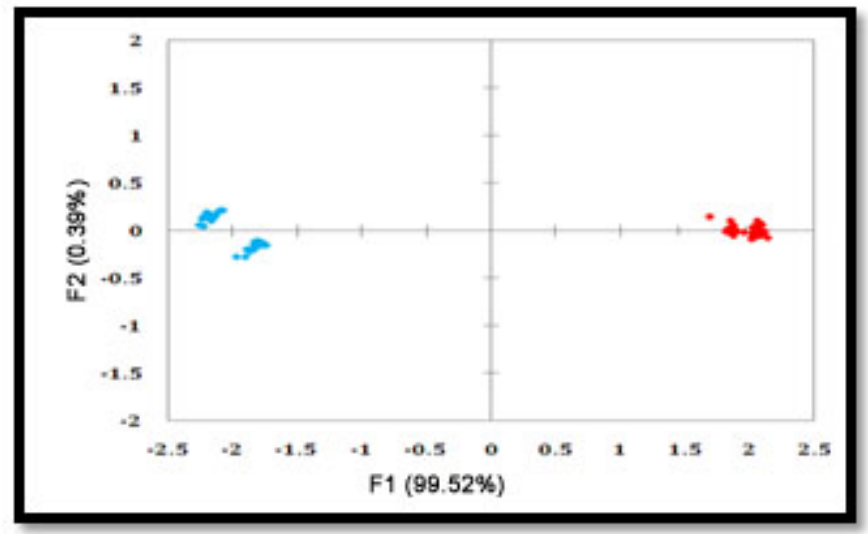

Figure 8 PCA plots for electronic nose response to Avon (Red) and Body Shop (Blue) perfumes 


\subsection{CONGLUSIONS}

As the conclusion, the designed electronic nose system can detect and discriminate between two types of perfumes successfully. This system consists of four different types of metal oxide semiconductor sensors with odour delivery components and signal conditioning circuitry. Owing to the sensors that be used in this system have different target gases, they will give different response for different odour. Therefore, their responses will be used to classify between the odours. The output voltage changes from initial stage to the maximum value that the sensor can be measured when it senses an odour. In addition, metal oxide semiconductor sensor is a suitable sensor to employ in an electronic nose system.

\section{REFERENCES}

[1] Figueiredo, S. A. B. and Stentiford, E. I. 2002. Evaluating the Potential of an Electronic Nose for Detecting the Onset of Anaerobic Conditions during Composting. School of Civil Engineering, University of Leeds, UK: Bioprocessing of Solid Waste \& Sludge.

[2] R. M. Stuetz, R. A. Fenner and G. Engin. 1999. Characterization of Wastewater Using an Electronic Nose. Wat. Res. 33(2): 442- 452.

[3] Andreas, V., V. Baier, R. Reisch, K. V. Roda, P. Elsner, H. Ahlers and G. Stein. 2005. Smelling Renal Dysfunction via Electronic Nose. Annals of Biomedical Engineering. 33(5): 656-660.

[4] M. Falasconi, M. Pardo, G. Sberveglieri, I. Ricco and A. Bresciani. 2005. The Novel EOS835 Electronic Nose and Data Analysis for Evaluating Coffee Ripening. Actuator and Sensors B. 110: 7380 .

[5] Ziyin, Y., F. Dong, K. Shimizu, T. Kinoshita, M., Kanamori, A. Morita and N. Watanabe. 2009. Identificatin of Coumarin - Enriched Japanese Green Teas and Their Particular Flavour using Electronic Nose. Journal of Food Engineering. 92: 312-316.

[6] Thorhas Bachinger and Carl - Fredrik Mandenius. 2000. Searching for Process Information in the Aroma of Cell Cultures. Trends in Biotechnology. 18(12): 494-500.

[7] Ping, W., Y. Tan, H. Xie and F. Shen. 1997. A Novel Method for Diabetes Diagnosis Based On Electronic Nose. Biosensors and Bioelectrics. 12(9-10): 1031-1036.

[8] Alexandros, K. P., N. Magan, Cliodna, M., J. M. Jones, D. Sharp, J. Brown and A. P. F. Turner. 2002. Use of an Electronic Nose System for Diagnoses of Urinary Tract Infections. Biosensors and Bioelectronics. 17(10): 893-899.

[9] Arnaldo, d'Amico, G. Pennazza, M. Santonico, E. Martinelli, C. Roscioni, G. Galluccio, R. Paolesse and C. Di Natale. 2009. An Investigation on Electronic Nose Diagnosis of Lung Cancer. Lung Cancer. 68(2): 170-176.

[10] Hiang, P. C., C. Lewis and P. S. Thomas. 2008. Exhaled Breath Analysis: Novel Approach for Early Detection of Lung Cancer. LungCancer. 63(2): 164-168. 